\title{
Evidence Supporting the Identity in Graves' Disease of Thyroid-stimulating Antibody and Thyroid Growth-promoting Immunoglobulin G as Assayed in FRTL5 Cells
}

\author{
Margita Zakarija, Shixin Jin, and J. Maxwell McKenzie \\ Department of Medicine, University of Miami School of Medicine, Miami, Florida 33101
}

\begin{abstract}
This paper addresses the question: in Graves' disease is there a thyroid-growth stimulating IgG (TGI) separate from thyroidstimulating antibody (TSAb)? Using the functioning rat thyroid line (FRTL5) cells for TGI (incorporation of $\left[{ }^{3} \mathrm{H}\right]-$ thymidine into DNA) and TSAb (increase in cAMP concentration) assays, we tested IgG from 30 Graves' patients. Positive TGI assay occurred only if cAMP increased in the cells and responses correlated, i.e., $r=0.95, P<0.001$. With one very potent TSAb-IgG we showed that Fab was active as TGI and TSAb, IgG with pI of 8.5-9.0 was the most potent fraction in both systems and an inhibitory IgG prevented the action of both TSAb-IgG and TSH in both the TSAb and TGI assays. In the last example, the action was on the cell membrane and not on the TSH or IgG. These data are entirely compatible with the view that in Graves' disease, at least as tested in FRTL5 cells, the same IgG is active in stimulating both growth and adenylate cyclase.
\end{abstract}

\section{Introduction}

In recent years the possibility has been raised that there may be a specific thyroid growth-stimulating $\mathrm{IgG}$ (TGI), ${ }^{1}$ distinct from the thyroid-stimulating antibody (TSAb) of Graves' disease, circulating in patients with simple goiter (1-4) or Graves' disease $(3,5)$. In addition, it was suggested that stimulation of thyroid growth may not be mediated by $\operatorname{cAMP}(1,3,6)$ unlike much of the rest of thyroid function (7), and despite the fact that such mediation was well documented for growth effects of TSH in canine thyroid cells (8-11). Recently, we addressed the question of whether TSH-stimulated growth (of the nontransformed functioning rat thyroid line, FRTL5 cells) was mediated by CAMP, and obtained data (12), as have others (13, 14), in support of that concept. We now describe experience with another aspect of the topic, viz., is it necessary to hypoth-

Address reprint requests to Dr. Zakarija, Department of Medicine (R-93), University of Miami School of Medicine, PO Box 016760, Miami, FL 33101. Dr. Jin's present address is the First Teaching Hospital, Xian Medical College, Xian, People's Republic of China.

Presented in part at the 61st Annual Meeting of the American Thyroid Association, Phoenix, AZ, September 1986.

Received for publication 7 July 1987 and in revised form 14 September 1987.

1. Abbreviations used in this paper: TGI, thyroid growth-promoting immunoglobulin G; TSAb, thyroid-stimulating antibody.

J. Clin. Invest.

(c) The American Society for Clinical Investigation, Inc.

0021-9738/88/03/0879/06 \$2.00

Volume 81, March 1988, 879-884 esize that in Graves' disease TSAb and TGI coexist as different molecules, or might the activities reflect the properties of a single IgG?

To this end we used three assay systems: increase in cAMP in human thyroid cells (15) and in FRTL5 cells (12) and increase in the incorporation of $\left[{ }^{3} \mathrm{H}\right]$ thymidine $\left(\left[{ }^{3} \mathrm{H}\right] \mathrm{Tdr}\right)$ into DNA in FRTL5 cells (12). We studied IgG from 30 patients with Graves' disease, including 16 previously reported (16), 12 listed in Table I, one whose data are given in Fig. 2 and one whose IgG acts as our laboratory standard TSAb, the assay characteristics of which have been described $(12,15)$.

\section{Methods}

Patients. The 30 patients studied all had a diagnosis of Graves' disease established by conventional clinical and laboratory criteria (17). Data from 16 of these patients were reported in brief previously (16). The additional $14 \mathrm{IgG}$ were chosen for the studies described here because of the wide ranges of responses obtained with them in the human thyroid cell assay (see Fig. 1 for results with $12 \mathrm{IgG}$ ). At the time blood was taken for the current investigation, the patients' clinical states varied from being hyperthyroid and freshly diagnosed to being hypothyroid but on thyroxine-replacement therapy after ablative treatment of hyperthyroidism (Table I); specific clinical features, such as goiter regrowth after subtotal thyroidectomy, are noted in the text.

IgG was purified from serum and concentrated as previously described (18); solutions were dialyzed against the buffer appropriate for the subsequent procedures and stored at $-20 \mathrm{C}$ until required. For more detailed studies, TSAb-IgG [our laboratory standard $(12,15)]^{2}$ was subjected to fractionation and fragmentation as follows: preparative isoelectric focusing was used (19) to obtain, from $90 \mathrm{mg} \mathrm{IgG}$, fractions with $\mathrm{pI} 5-6.5,-7.5,-8.0,-8.5,-9.0,-9.5$, and -10.0 . These solutions were dialyzed for $4 \mathrm{~h}$ against distilled water, for $24 \mathrm{~h}$ against $0.9 \% \mathrm{NaCl}$ and then concentrated by vacuum filtration followed by further dialysis versus two changes of $0.9 \% \mathrm{NaCl}$ over $48 \mathrm{~h}$. To ensure total removal of ampholyte, the first three fractions [known to retain residual ampholyte (18)] were passed over a 5-ml column of Sephadex G-50 equilibrated with $20 \mathrm{mM}$ Tris $\mathrm{HCl}, 50 \mathrm{mM} \mathrm{NaCl}, \mathrm{pH}$ 7.5. The final solutions were dialyzed against the buffer appropriate for the assay to be undertaken. The Fab fragment of TSAb-IgG was prepared as described previously (15). It was pure as tested with rabbit antihuman IgG/Fc (Behringwerke AG, Marburg, FRG) by the Ouchterlony technique (15).

An IgG that is a potent inhibitor of both TSAb and TSH (designated MIgG in reference 15) was used as indicated to test effects in TSAb and TGI assays, by itself and as an inhibitor of TSH and TSAb in

2. This IgG was prepared from the serum of a patient who, after giving birth to a hyperthyroid neonate, was treated with ${ }^{131} I$ and subsequently maintained on $\mathrm{T}_{4}$. As this is the most potent TSAb in our experience and without a biphasic effect in cAMP assays, we have been using it as our laboratory standard (reference 12, TSAb; reference 15, DeL IgG). There has been no change in potency in this patient's IgG over $4 \mathrm{yr}$. IgG from $9 / 82$ and $8 / 86$ were tested simultaneously at $10 \mu \mathrm{g} / \mathrm{ml}$ (human thyroid cells); results were 570 and $571 \%$ inciease in cAMP. 
Table I. Thyroid Gland Size, Therapy, and Assay Data for 12 Patients with Graves' Disease

\begin{tabular}{cccccc}
\hline & & & & \multicolumn{2}{c}{ Assay data (FRTL5 cells) } \\
\cline { 5 - 6 } $\begin{array}{c}\text { Patient } \\
\text { No. }\end{array}$ & Thyroid & Therapy* & IgG & cAMP & [ $\left.{ }^{3} \mathrm{H}\right] \mathrm{Tdr}$ \\
\hline & $g$ & & $m g / m l$ & $\%$ & $\%$ \\
1 & $45^{\ddagger}$ & Nil & $0.2-4$ & $105-75$ & $103-70$ \\
2 & $145^{\ddagger}$ & Nil & $0.2-4$ & $98-85$ & $66-88$ \\
3 & $120^{\ddagger}$ & PTU & $0.2-4$ & $96-96$ & $100-72$ \\
4 & $50^{\S}$ & PTU & $0.2-4$ & $96-95$ & $95-100$ \\
5 & $60^{\S}$ & PTU & $0.2-4$ & $106-125$ & $105-92$ \\
6 & $185^{\ddagger}$ & T4 & $0.2-4$ & $846-1203$ & $870-820$ \\
7 & $60^{\S}$ & PTU & $0.2-4$ & $863-1208$ & $872-870$ \\
8 & $80^{\S}$ & PTU & $1.0-4$ & $282-1402$ & $510-969$ \\
9 & $180^{\S}$ & Nil & $1.0-4$ & $930-3788$ & $985-936$ \\
10 & $160^{\S}$ & Nil & $1.0-4$ & $451-1732$ & $704-960$ \\
11 & $80^{\S}$ & PTU & $0.2-1$ & $697-2850$ & $963-962$ \\
12 & $0^{\S}$ & T & $0.2-1$ & $1100-3462$ & $970-951$ \\
& & & & &
\end{tabular}

* At time blood was obtained; PTU, propylthiouracil; $\mathrm{T}_{4}$, thyroxine, prescribed for hypothyroidism that developed $5 \mathrm{wk}$ after subtotal thyroidectomy (patient 6) or 3 doses of ${ }^{131}$ I (patient 12). Blood for TGI and TSAb assays was obtained shortly before (patients 1-3) or after (patient 6) subtotal thyroidectomy. Where it was from patients under therapy with PTU all had suppressed TSH so that the thyroid weight was presumably not influenced by therapy in all except patient 12 . Thyroid weight: ${ }^{*}$ confirmed at operation; ${ }^{8}$ clinical estimate. Assay data are the means of triplicate observations obtained with the two concentrations of IgG listed; in most instances intermediate concentration of IgG was also tested. cAMP-\% and $\left[{ }^{3} \mathrm{H}\right] \mathrm{Tdr}$ refer to values expressed as percentage of control (12); in both systems IgG 1-5 were not stimulatory. In the TSAb assay the maximum response to TSH $(5 \mathrm{mU} / \mathrm{ml})$ was $6596 \%$ and in TGI assay $(200$ $\mu \mathrm{U} / \mathrm{ml}$ ) $973 \%$. As discussed in the text, the TGI assay response is maximal at lower concentrations of TSH and IgG than occurs in the TSAb system.

both systems. To exclude the possibility that the inhibitor interacted directly with TSH and TSAb-IgG, some assays were carried out by preincubating cells with the inhibiting IgG, then washing them with buffer before incubation with test materials. In this report the laboratory standard TSAb-IgG is referred to as TSAb or TSAb-IgG and the inhibiting IgG as IgG-i. TSH used was NIH-TSH-B-10, a gift from National Institute of Diabetes, Digestive and Kidney Diseases, NIH.

$T S A b$ assay with human thyroid and FRTL5 cells in culture. FRTL5 cells were generously provided by Dr. L. D. Kohn and Dr. W. A. Valente of NIH and were used as described (12). The procedure for human thyroid cells, in hypotonic medium, was also reported previously (15). In both instances cAMP was measured by radioimmunoassay kit (Immuno Nuclear Corporation, Stillwater, MN); with the FRTL5 cells an ethanol extract of cells was processed (12) and with human cells aliquots of medium were used directly after dilution and acetylation (15). The incubation time with IgG or TSH was $2 \mathrm{~h}$ with FRTL5 cells and $4 \mathrm{~h}$ with human cells.

TGI assay. FRTL5 cells were used as described earlier (12) with increase in DNA and in the incorporation of $\left[{ }^{3} \mathrm{H}\right] \mathrm{Td}$ into DNA as indices of growth. The incubation time with IgG or TSH was $72 \mathrm{~h}$.

Statistical methods. Analysis of variance was used to establish the statistical significance of assay data. Correlation coefficient was calculated by linear regression analysis.

\section{Results}

Assays in human thyroid cells. These were carried out at two or three concentrations of IgG, typically $0.05,0.5$, and $1.5 \mathrm{mg} / \mathrm{ml}$ hypotonic medium, as previously described $(15,20)$. All 30 samples were positive at one or more concentrations. Illustrative data with IgG from 12 patients are given in Fig. 1. As we have emphasized in an earlier publication (20), the response to the three doses of IgG tested may vary from straight-line positive slope (e.g., IgG 8), through biphasic (e.g., IgG 3), to a straight-line negative slope (e.g., patient 6). Also shown in the figure is the fact that the least potent $\operatorname{IgG}(1-5)$ were negative in the FRTL5-cAMP assay and all others were positive. This aspect of the study is enlarged below.

Assays with FRTL5 cells. Of the $30 \mathrm{IgG}, 17$ were positive in terms of both cAMP production and $\left[{ }^{3} \mathrm{H}\right] \mathrm{Tdr}$ incorporation; 4 were low positive $(<180 \%)$ as TSAb but negative in the TGI assay; 8 were negative in both procedures; data for the 12 most recently studied IgG are in Table I. We had the opportunity to obtain repeatedly IgG from 1 patient and her data are detailed below.

There was no correlation of the data from any of the three assay systems, specifically the TGI procedure, with estimated goiter size (Table I). On the other hand, as indicated in Table I, TGI negative IgG were also negative in the FRTL5-cAMP assay and were the least potent in the human thyroid cell assay. A correlation coefficient of $0.95, P<0.001$, resulted when the values obtained with the lowest IgG concentrations in the 12 duplicate sets of data were used to compare results of TSAb versus TGI assays. The values with the highest IgG concentrations were not as satisfactory for analysis since some represented data after the maximum responsiveness of the TGI assay was reached.

Studies with individual IgG. Fig. 2 provides data with IgG collected over time from a patient initially treated with propylthiouracil (from 3/84) and then subjected twice to subtotal thyroidectomy (in June 1985 and June 1986 after relapse of hypothyroidism with goiter regrowth), before requiring thyroxine therapy for hypothyroidism. The patterns of assay response (human thyroid cells) illustrate a change from negative to positive slopes over the concentrations tested. The figure also depicts assay results using FRTL5 cells. No IgG was available from the blood of $3 / 84$ but the four other IgG were assayed for effects on both cAMP concentration and $\left[{ }^{3} \mathrm{H}\right] \mathrm{Tdr}$ incorporation. Only samples from $1 / 85$ and $7 / 85$ enhanced

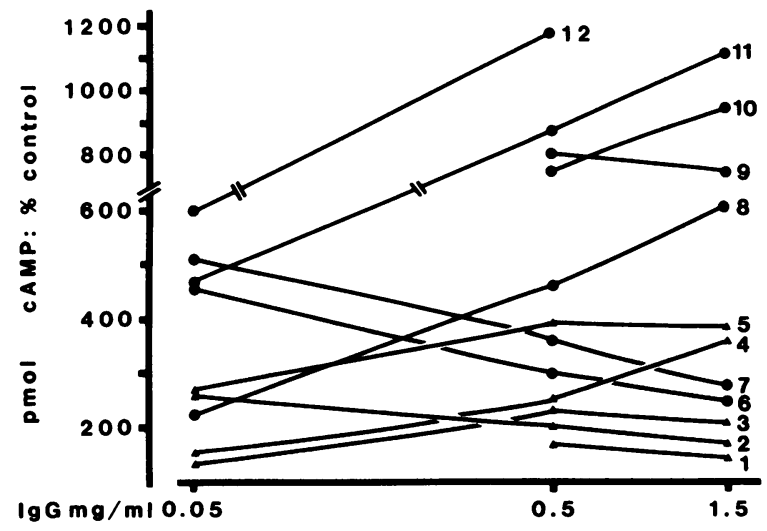

Figure 1. TSAb assay with human thyroid cells. Numbers 1-12 refer to IgG purified from sera of patients in Table I. Values shown were derived from 3 separate assays in which responses to $1 \mathrm{mU} \mathrm{TSH} / \mathrm{ml}$ were $1,105-1,204 \%$. Each point represents the mean of closely agreeing triplicate determination. $\triangle$ Samples negative in TSAb and TGI assays with FRTL5 cells; $\bullet$ all positive in FRTL5 systems. 
cAMP concentration, as shown; IgG from $8 / 86$ and $12 / 86$ were negative as tested at a maximum of $4 \mathrm{mg} / \mathrm{ml}$. In the TGI assay (data not shown) all IgG were negative except that of $1 / 85$, which at $4 \mathrm{mg} / \mathrm{ml}$ gave a response of $463 \%$.

Assay of fractions obtained by isoelectric focusing. Fig. 3 offers a comparison of increasing concentrations of the IgG fractions, obtained by isoelectric focusing, that were tested in the TSAb and TGI assays with FRTL5 cells. The following features merit emphasis. In the TSAb assay there is a progressive increment of response to $10-200 \mu \mathrm{U} \mathrm{TSH} / \mathrm{ml}$; none of the IgG fractions stimulated the system to the degree obtained with $200 \mu \mathrm{U} \mathrm{TSH} / \mathrm{ml}$. For each concentration of IgG the greatest effect was obtained with fraction 5, i.e., with pI of 8.5-9.0. With the TGI assay, as judged by the response to TSH, a maximal response of $\sim 650-700 \%$ was achieved with fractions 4-6 at $50 \mu \mathrm{g} / \mathrm{ml}$ and fractions $3-7$ at $200 \mu \mathrm{g} / \mathrm{ml}$. However, with $10 \mu \mathrm{g} / \mathrm{ml}$ the greatest response was clearly obtained with fraction 5 (pI 8.5-9.0). As reported previously (12), it is characteristic of these assays that the maximum effect is readily reached with lower quantities of either IgG or TSH in the TGI system than in the TSAb assay. A similar pattern of response relative to the pI of the fractions was obtained in the TSAb assay with human thyroid cells except that there was greater sensitivity in that system; when IgG was tested at 1,5 , and $50 \mu \mathrm{g} / \mathrm{ml}$, a maximum effect was observed with $5 \mu \mathrm{g}$ of fraction 5 (data not shown).

Table II provides data from the same experiment but with the growth effect shown as micrograms of DNA/well; there was confirmation of a true growth effect with 50 and $200 \mu \mathrm{g}$ $\mathrm{IgG} / \mathrm{ml}$. Using the lower concentration, the greatest increase in DNA was obtained with fraction 5 but with $200 \mu \mathrm{g} / \mathrm{ml}$ all responses, except for that of fraction 2 , were to the apparent maximum of the system, as was the case with the $\left[{ }^{3} \mathrm{H}\right] \mathrm{Tdr}$ incorporation.

TSAb and TGI assays of Fab fragment of TSAb-IgG. As shown in Fig. 4 in the TSAb assay the Fab fragment of the standard TSAb-IgG was, by weight, more potent than the parent IgG; we have previously documented that on a molar basis the Fab component is approximately equipotent to the parent IgG (15). We have no explanation why, in this instance, the Fab fragment was apparently of significantly greater molar potency than the parent IgG. In the TGI assay the maximal

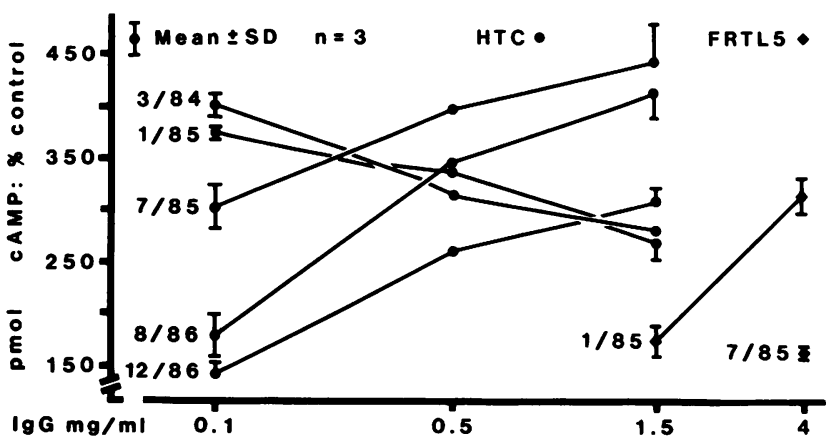

Figure 2. TSAb assay with human thyroid (HTCø) and FRTL5 cells ( $\bullet$ ). IgG was obtained from serum of a single patient (clinical course described in the text) on the dates indicated. Samples $3 / 84$ to $8 / 86$ (HTC) were tested in a single assay and that of $12 / 86$ subsequently; response to $1 \mathrm{mU} \mathrm{TSH} / \mathrm{ml}$ in those assays was 1,174 and $1,271 \%$. Samples $1 / 85$ to $12 / 86$, as described in the text, were tested in a single FRTL5 assay. (Modified from Fig. 3, reference 30 by inclusion of data with FRTL5 cells.)
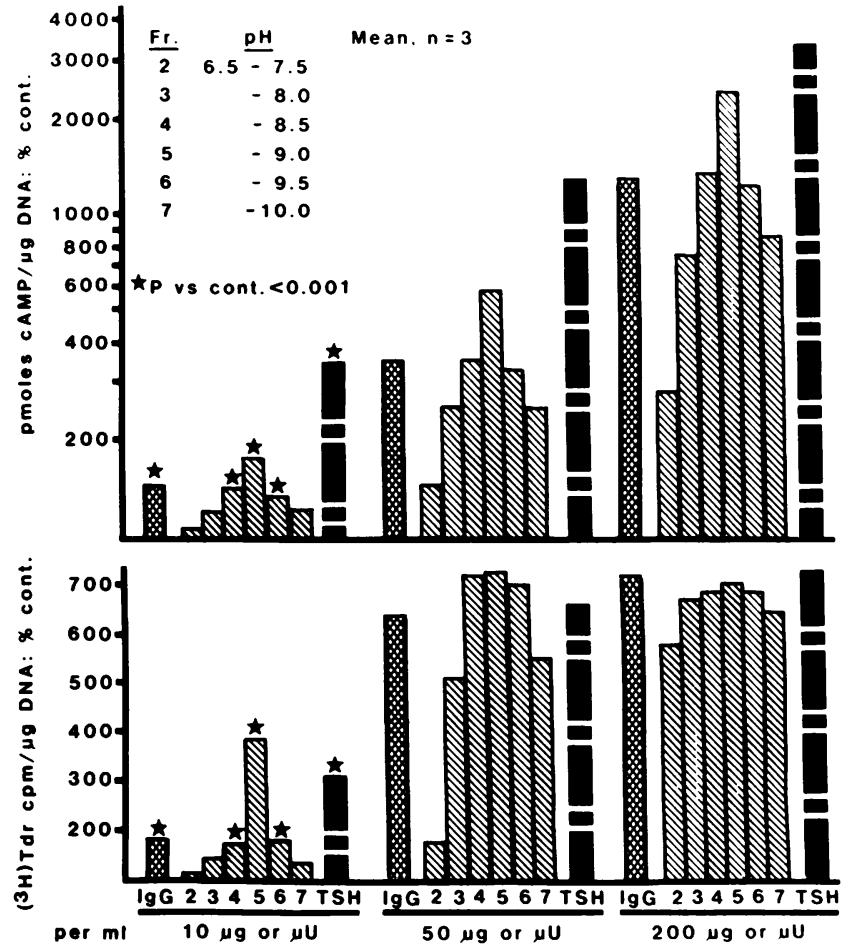

Figure 3. Effect of IEF fractions of TSAb-IgG in TSAb and TGI assays with FRTL5 cells. In the two systems, all samples were tested in single assay runs. The statistical significance of responses to $10 \mu \mathrm{g}$ or $\mu \mathrm{U}$ is indicated; all responses to 50 or $200 \mu \mathrm{g}$ or $\mu \mathrm{U}$ were significantly different from the control $(P<0.001)$.

effect (as judged by the response to $200 \mu \mathrm{U} \mathrm{TSH} / \mathrm{ml}$, not shown) was achieved by $10-50 \mu \mathrm{g} \mathrm{Fab} / \mathrm{ml}$ but only by $50-200$ $\mu \mathrm{g} \mathrm{IgG.} \mathrm{A} \mathrm{similar} \mathrm{pattern} \mathrm{(not} \mathrm{shown)} \mathrm{was} \mathrm{obtained} \mathrm{when} \mathrm{an}$ increase in DNA/well was used as the index of response. Thus in stimulation both of cAMP accumulation and growth the Fab fragment of the parent IgG had full potency.

Inhibition of TSAb, TGI, and TSH. IgG-i was previously shown to be a potent inhibitor, in the TSAb assay, of both TSH and TSAb-IgG (15). It was therefore of interest to test it in the TGI assay and the data are given in Fig. 5. IgG-i had a slight negative effect by itself, and TSAb and TSH were stimulatory at $20 \mu \mathrm{g}$ and $20 \mu \mathrm{U}$ per ml; these effects of TSAb and TSH were completely inhibited by addition of IgG-i to the system.

The mechanism of inhibition of TSAb-IgG and TSH by IgG-i in the TSAb assay was explored as shown in Fig. 6. In this experiment cells were pre-incubated with $1 \mathrm{mg}$ IgG-i or normal IgG per $\mathrm{ml}$ buffer for $1 \mathrm{~h}$ before they were washed and used for the TSAb assay. The effect of only preincubation with IgG-i was to inhibit both stimulators by $>90 \%$; there was complete inhibition when TSH and TSAb were assayed with IgG-i included in the second incubation. Similar results were obtained when another inhibitory IgG was tested in like fashion (data not shown).

\section{Discussion}

These experiments were aimed at testing the hypothesis that there may be different IgG molecules in Graves' disease that are active in TSAb and TGI assays. Our findings are compatible with the view that the same IgG is active in both systems.

As emphasized previously we consider it important, when using human thyroid cells, to assay samples for TSAb at sev- 
Table II. TGI Assay of Isoelectric Focusing Fractions of TSAb-IgG

\begin{tabular}{lccc}
\hline & \multicolumn{3}{c}{$\mu \mathrm{g}$ DNA/well at IgG concentration } \\
\cline { 2 - 4 } Group & $10 \mu \mathrm{g} / \mathrm{ml}$ & $50 \mu \mathrm{g} / \mathrm{ml}$ & $200 \mu \mathrm{g} / \mathrm{ml}$ \\
\hline Control & $4.29 \pm 0.17^{*}$ & $4.15 \pm 0.07$ & $4.19 \pm 0.11$ \\
TSAb-IgG & $4.28 \pm 0.19$ & $5.86 \pm 0.19^{\ddagger}$ & $6.50 \pm 0.06^{\ddagger}$ \\
Fr. 2 & $4.38 \pm 0.24$ & $4.32 \pm 0.25$ & $5.20 \pm 0.15^{\ddagger}$ \\
3 & $4.12 \pm 0.17$ & $5.22 \pm 0.15^{\ddagger}$ & $6.15 \pm 0.17^{\ddagger}$ \\
4 & $4.39 \pm 0.08$ & $5.72 \pm 0.23^{\ddagger}$ & $6.66 \pm 0.08^{\ddagger}$ \\
5 & $4.52 \pm 0.18$ & $6.43 \pm 0.17^{\ddagger}$ & $6.39 \pm 0.06^{\ddagger}$ \\
6 & $4.46 \pm 0.15$ & $5.50 \pm 0.30^{\ddagger}$ & $6.46 \pm 0.09^{\ddagger}$ \\
7 & $4.40 \pm 0.02$ & $5.10 \pm 0.11^{\ddagger}$ & $6.25 \pm 0.14^{\ddagger}$
\end{tabular}

The fraction (Fr.) number refers to those identified by pI in Fig. 3. The DNA values in this table are those used to calculate the response $\left(\left[{ }^{3} \mathrm{H}\right] \mathrm{Tdr} / \mu \mathrm{g}\right.$ DNA) in Fig. 3.

* Mean \pm SD, $n=3$.

${ }^{\ddagger} P$ vs. control: $<0.001$.

eral concentrations of IgG in that, at a single concentration, some will appear negative while actually positive at a higher or lower level. This biphasic effect in the assay may reflect the presence of an IgG with the property of inhibiting TSAb (15). Assuming different potencies and/or affinities of a stimulator and an inhibitor, the response in the TSAb assay will clearly vary with the relative concentrations of the IgG concerned and this, in turn, will inevitably differ from patient to patient.

Comparison of responses to IgG in the three assay systems is fraught with difficulty. In general it is clear that, with FRTL5 cells, only if there is a positive TSAb effect of a certain magnitude, i.e., in our hands, an increase in cAMP accumulation of at least $180 \%$, is there stimulation of $\left[{ }^{3} \mathrm{H}\right] \mathrm{Tdr}$ incorporation. Secondly, overall in the two TSAb assay systems, the response of human thyroid cells is greater than that of FRTL5 cells, although direct comparison is complicated by the biphasic responses (Fig. 1) that occur more frequently with the former. In our experience, a response in the human system of at least $400 \%$ increase in cAMP with one concentration of $\mathrm{IgG}$ was obtained if that IgG was positive in the TGI system. Furthermore, as illustrated by the data in Fig. 2 and Table I, there was no correlation between the clinical assessment of thyroid

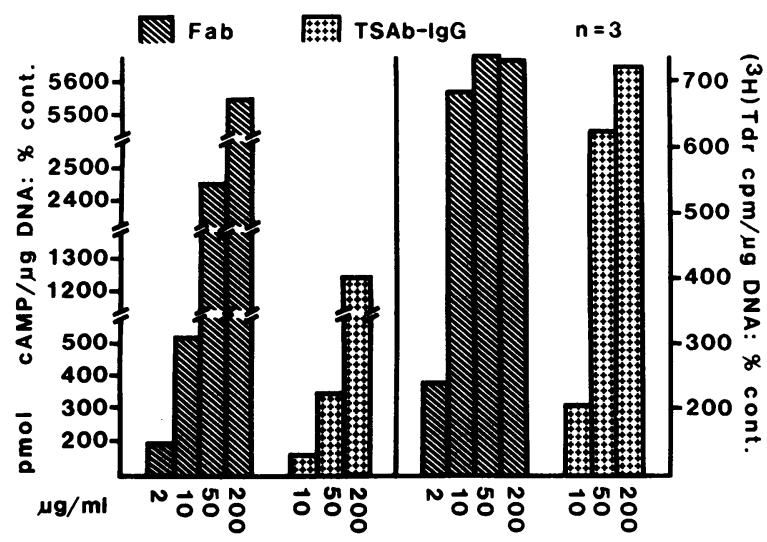

Figure 4. Effect of TSAb-IgG and its Fab fragment in TSAb and TGI assay using FRTL5 cells. All values are the means of closely agreeing triplicate observations and are statistically significantly greater than control $(P<0.001)$.

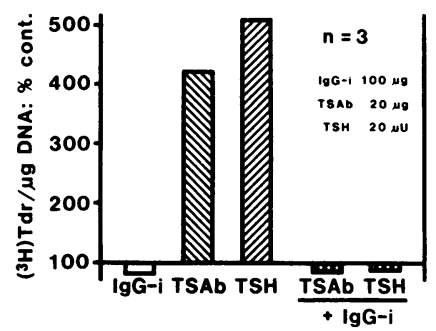

Figure 5. Inhibition by IgG-i of TSAb- and TSH- induced incorporation of $\left[{ }^{3} \mathrm{H}\right] \mathrm{Tdr}$ in FRTL5 cells. All values are the means of closely agreeing triplicate observations.

growth (Fig. 2) or goiter size (Table I) and any of the assay data. The degree to which an inhibitor of TSAb, referred to above and characterized previously (15), enters into divergence of TSAb assay data (human cells) and thyroid size is unclear. On the other hand, overall our data indicate that an IgG that is strongly positive in the human thyroid cell system will be positive in both FRTL5 cell assays.

Turning to more detailed studies with a single IgG, we aimed to compare several qualitative aspects of the $\mathrm{IgG}$ as tested in the TSAb and TGI assays. Evidence was obtained that the greatest stimulatory fraction of IgG, separated by isoelectric focusing, was the same, at least within the analytical limitations of the technique used, for both assays. As already emphasized in the results section, the lower maximal responsiveness of the TGI procedure makes comparisons of this nature less than straightforward; recognizing this difference in the assays, and the inevitable cross-contamination of fractions by large-scale preparative isoelectric focusing, the pI of the most active IgG for stimulation of growth was 8.5 to 9.0 , similar to that with TSAb [also reported with other TSAb assay techniques (19)]. This implies, at a minimum, that the membrane component to which IgG binds for the TGI effect has a pI similar to that for the TSAb effect, viz., acidic and complementary to the alkaline pI of the IgG.

The second point is that growth-stimulation, like the TSAb effect, does not require a divalent IgG molecule. Antibodies to the insulin and acetylcholine receptors have been shown to act only as whole IgG or $\mathrm{F}\left(\mathrm{ab}^{\prime}\right)_{2}$ but not as Fab $(21,22)$. This is unlike TSAb that is active as Fab (15). The implications of both growth and cAMP increase being positively affected by a monovalent fragment suggest that cross-linking of the TSH receptor is not necessary for either effect. However, for the present purpose one may merely accept that the findings make more likely the identity of TSAb and TGI in the patient's IgG.

The final point is that TSAb and TGI activities of both

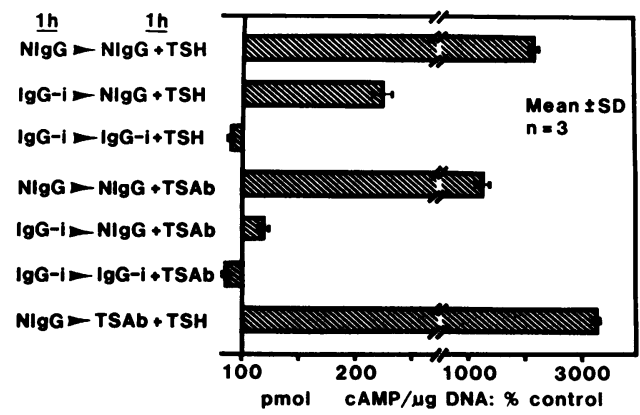

Figure 6. Inhibition by IgG-i of TSAb- and TSH- induced cAMP accumulation in FRTL5 cells. Cells were preincubated for $1 \mathrm{~h}$, then thoroughly washed and incubated for an additional $\mathrm{h}$ with test material as noted: $\mathrm{N}$ (normal) IgG $1 \mathrm{mg}$, TSAb- IgG $0.4 \mathrm{mg}$, IgG-i $1 \mathrm{mg}$, TSH $0.1 \mathrm{mU} / \mathrm{ml}$. 
TSH and the patient's IgG were inhibited by the action of a single IgG. Again, one interpretation of the data is that this inhibition reflects an action on a common pathway, i.e., involving adenylate cyclase. The mode of such inhibition is not established but from the study depicted in Fig. 6 it seems clear that the action is on the membrane, presumably on the TSH receptor itself, and not on the stimulating molecules, i.e., TSH or TSAb. An antibody to TSAb, i.e., an antiidiotype, was suggested by others (23) who studied the same patient's IgG; our data clearly refute this possibility. Since the TGI assay requires at least $48 \mathrm{~h}$ (12), it is not possible similarly to test the mode of inhibition in that procedure, but it may be reasonable to assume that the same mechanism is involved. These inhibition data do not, of themselves, speak for a single IgG acting as both TSAb and TGI but are contrary to the view that not only are these separable IgG, but that they act through distinct pathways (3).

To summarize, we have reported data from both a survey of 30 patients' IgG tested in three assay systems, and detailed studies of the characteristics of a potent TSAb-IgG that is active in these TSAb and TGI assay procedures. Our interpretation is that in Graves' disease the IgG that stimulates adenylate cyclase is the same as that which stimulates growth. These conclusions are contrary to those reached by others who, using FRTL5 cells, studied IgG from a series of patients and found divergence in assay results, TSAb versus TGI (5). The latter findings were in keeping with the results of other experiments apparently showing that stimulation of growth and adenylate cyclase in FRTL5 cells was due to separate bioeffects of TSH (6). However, we and others (8-14) have reported that cAMP is indeed a mediator of the growth-promoting action of TSH and therefore probably also of TSAb.

Clearly our findings need have little bearing on claims that there may be a specific "TGI" in other goitrous states (1-4) or that there are growth pathways mediated by other than cAMP; indeed data have accumulated $(10,11,24-30)$ in accord with the existence of a non-cAMP route for thyroid growth stimulation. Consequently, we restrict interpretation of our current observations to their being in keeping with the view that in Graves' disease, TSAb action, through adenylate cyclase, is sufficient to explain thyroid growth. A role in vivo for other IgG or growth factors is possible. Regarding correlates of goiter size with assay data, it is probable that more than a single bioactive substance will influence thyroid growth in an individual patient. Apart from the coexistence of TSAb and other antibodies that affect the TSH receptor (reviewed in 31), it is now recognized that $\gamma$-interferon may reduce TSH-stimulated thyroid cell metabolism (32) and growth (33) in vitro. It is thus feasible that in vivo, particularly in thyroids with marked lymphocytic infiltration, such action of $\gamma$-interferon might modulate the size of the goiter.

An important caveat is that in these studies we, and others, speculate on the basis of data obtained with model systems, e.g., FRTL5 cells; a significant achievement will be development of a human thyroid cell line retaining all differentiated functions, including responsiveness to growth stimuli.

\section{Acknowledgments}

Appreciation is expressed to Mrs. Jean Zegadlo for her technical assistance. J. M. McKenzie is the Kathleen and Stanley Glaser Professor of Medicine.

Supported by U. S. Public Health Service grant AM-31391.

\section{References}

1. Drexhage, H. A., G. F. Bottazzo, D. Doniach, L. Bitensky, and J. Chayen. 1980. Evidence for thyroid-growth-stimulating immunoglobulins in some goitrous thyroid disease. Lancet. 2:287-292.

2. McMullan, N. M., and P. P. A. Smyth. 1984. In vitro generation of NADPH as an index of thyroid stimulating immunoglobulins (TGI) in goitrous disease. Clin. Endocrinol. (Oxford). 20:269-280.

3. Kohn, L. D., W. A. Valente, F. V. Alvarez, C. M. Rotella, C. Marcocci, R. S. Toccafondi, and E. F. Grollman. 1985. New procedures for detecting Graves' immunoglobulins. In Autoimmunity and the Thyroid. P. G. Walfish, J. R. Wall, and R. Volpe, editors. Academic Press, New York. 217-247.

4. Medeiros-Neto, G., A. Halpern, Z. S. Cozzi, N. Lima, and L. D. Kohn. 1986. Thyroid growth immunoglobulins in large multinodular endemic goiters: effect of iodized oil. J. Clin. Endocrinol. Metab. 63:644-650.

5. Valente, W. A., P. Vitti, C. M. Rotella, M. M. Vaughan, S. M. Aloj, E. F. Grollman, F. S. Ambesi-Impiombato, and L. D. Kohn. 1983. Antibodies that promote thyroid growth. A distinct population of thyroid-stimulating autoantibodies. N. Engl. J. Med. 309:10281034.

6. Valente, W. A., P. Vitti, L. D. Kohn, M. L. Brandi, C. M. Rotella, R. S. Toccafondi, D. Tramontano, S. M. Aloj, and F. S. Ambesi-Impiombato. 1983. The relationship of growth and adenylate cyclase activity in cultured thyroid cells: separate bioeffects of thyrotropin. Endocrinology. 112:71-79.

7. Dumont, J. E. 1971. The action of thyrotropin on thyroid metabolism. Vitam. Horm. 29:287-412.

8. Roger, P. P., A. Hotimsky, C. Moreau, and J. E. Dumont. 1982. Stimulation by thyrotropin, cholera toxin and dibutyryl cyclic AMP of the multiplication of differentiated thyroid cells in vitro. Mol. Cell. Endocrinol. 26:165-176.

9. Roger, P. P., P. Servais, and J. E. Dumont. 1983. Stimulation by thyrotropin and cyclic AMP of the proliferation of quiescent canine thyroid cells cultured in a defined medium containing insulin. FEBS (Fed. Eur. Biochem. Soc.) Lett. 157:323-329.

10. Roger, P. P., S. Reuse, P. Servais, B. Van Heuverswyn, and J. E. Dumont. 1986. Stimulation of cell proliferation and inhibition of differentiation expression by tumor-promoting phorbol esters in dog thyroid cells in primary culture. Cancer Res. 46:898-906.

11. Roger, P. P., P. Servais, and J. E. Dumont. 1987. Induction of DNA synthesis in dog thyrocytes in primary culture: synergistic effects of thyrotropin and cyclic AMP with epidermal growth factor and insulin. J. Cell. Physiol. 130:58-67.

12. Jin, S., F. J. Hornicek, D. Neylan, M. Zakarija, and J. M. McKenzie. 1986. Evidence that adenosine 3', $5^{\prime}$-monophosphate mediates stimulation of thyroid growth in FRTL-5 cells. Endocrinology. 119:802-810.

13. Ealey, P. A., J. M. Emmerson, S. P. Bidey, and N. J. Marshall. 1985. Thyrotrophin stimulation of mitogenesis of the rat thyroid cell strain FRTL-5: a metaphase index assay for the detection of thyroid growth stimulators. J. Endocrinol. 106:203-209.

14. Dere, W. H., and B. Rapoport. 1986. Control of growth in cultured rat thyroid cells. Mol. Cell. Endocrinol. 44:195-199.

15. Zakarija, M., A. Garcia, and J. M. McKenzie. 1985. Studies on multiple thyroid cell membrane directed antibodies in Graves' disease. J. Clin. Invest. 76:1885-1891.

16. Neylan, D., M. Zakarija, A. J. Claflin, and J. M. McKenzie. 1986. Evidence that stimulation of thyroid growth is mediated by cyclic AMP (cAMP). In Frontiers in Thyroidology. G. Medeiros-Neto, and E. Gaitan, editors. Vol. 2. Plenum Publishing Corporation, New York. 1469-1472.

17. McKenzie, J. M., M. Zakarija, and M. Bonnyns. 1979. Hyperthyroidism. In Endocrinology. L. J. Degroot, G. F. Cahill, L. Martini, D. H. Nelson, W. D. Odell, J. T. Potts, Jr., E. Steinberg, and A. I. Winegrad, editors. Vol. 1. Grune \& Stratton, New York. 429-459.

18. Zakarija, M. 1980. Thyroid-stimulating antibody (TSAb) of 
Graves' disease: evidence for restricted heterogeneity. Horm. Res. 13:1-15.

19. Zakarija, M., and J. M. McKenzie. 1978. Isoelectric focusing of thyroid-stimulating antibody of Graves' disease. Endocrinology. 103:1469-1475.

20. Zakarija, M., J. M. McKenzie, and A. Claflin. 1985. Humoral aspects of Graves' disease. In Autoimmunity and the Thyroid. P. G. Walfish, J. R. Wall, and R. Volpe, editors. Academic Press, Orlando, FL. 109-124.

21. Kahn, C. R., K. L. Baird, D. B. Jarrett, and J. S. Flier. 1978. Direct demonstration that receptor cross-linking or aggregation is important in insulin action. Proc. Natl. Acad. Sci. USA. 75:4209-4213.

22. Lindstrom, J., S. Tzartos, and B. Gullick. 1981. Structure and function of acetylcholine receptors studied using monoclonal antibodies. Ann. NY Acad. Sci. 377:1-19.

23. Kohn, L. D., F. Alvarez, C. Marcocci, A. D. Kohn, D. Corda, W. E. Hoffman, D. Tombaccini, W. A. Valente, M. DeLuca, P. Santisteban, and E. F. Grollman. 1986. Monoclonal antibody studies defining the origin and properties of autoantibodies in Graves' disease. Ann. NY Acad. Sci. 475:157-173.

24. Roger, P. P., and J. E. Dumont. 1984. Factors controlling proliferation and differentiation of canine thyroid cells cultured in reduced serum conditions: Effects of thyrotropin, cyclic AMP and growth factors. Mol. Cell. Endocrinol. 36:79-93.

25. Westermark, K., F. A. Karlsson, and B. Westermark. 1983. Epidermal growth factor modulates thyroid growth and function in culture. Endocrinology. 112:1680-1686.

26. Eggo, M. C., L. K. Bachrach, G. Fayet, J. Erric, J. E. Kudlow, M. F. Cohen, and G. N. Burrow. 1984. The effects of growth factors and serum on DNA synthesis and differentiation in thyroid cells in culture. Mol. Cell. Endocrinol. 38:141-150.

27. Bachrach, L. K., M. C. Eggo, W. W. Mak, and G. N. Burrow. 1985. Phorbol esters stimulate growth and inhibit differentiation in cultured thyroid cells. Endocrinology. 116:1603-1609.

28. Tramontano, D., G. W. Cushing, A. C. Moses, and S. H. Ingbar. 1986. Insulin-like growth factor-I stimulates the growth of rat thyroid cells in culture and synergizes the stimulation of DNA synthesis induced by TSH and Graves'-IgG. Endocrinology. 119:940-942.

29. Mine, M., D. Tramontano, W. W. Chin, and S. H. Ingbar. 1987. Interleukin-1 stimulates thyroid cell growth and increases the concentration of the c-myc proto-oncogene mRNA in thyroid follicular cells in culture. Endocrinology. 120:1212-1214.

30. Zakarija, M. 1987. Heterogeneity of TSH receptor-directed antibodies (TRAb) and their significance. In Thyroid Autoimmunity, 30th Anniversary: Memories and Perspectives. A Pinchera, S. H. Ingbar, and J. M. McKenzie, editors. Plenum Press, London. In press.

31. Zakarija, M., and J. M. McKenzie. 1987. The spectrum and significance of autoantibodies reacting with the thyrotropin receptor. Endocrinol. Metab. Clin. N. Am. 16:343-363.

32. Nagayama, Y., M. Izumi, K. Ashizawa, T. Kiriyama, N. Yokoyama, S. Morita, S. Ohtakara, T. Fukuda, K. Eguchi, I. Morimoto, S. Okamoto, N. Ishikawa, K. Ito, and S. Nagataki. 1987. Inhibitory effect of interferon- $\gamma$ on the response of human thyrocytes to thyrotropin (TSH) stimulation: relationship between the response to TSH and the expression of DR antigen. J. Clin. Endocrinol. Metab. 64:949-953.

33. Zakarija, M., S. Levis, F. J. Hornicek, and J. M. McKenzie. 1987. Effects of $\gamma$-interferon (IFN) on FRTL5 cells. Program of the 16th Annual Meeting of the European Thyroid Association. (Abstr.) 